\title{
Effect of pretreatment conditions on catalytic activity of Ag/SBA-15 catalyst for toluene oxidation
}

\author{
Yuan Qin, Zhenping Qu *, Cui Dong, Na Huang \\ Key Laboratory of Industrial Ecology and Environmental Engineering (MOE), School of Environmental Science and Technology, Dalian University of \\ Technology, Dalian 116024, Liaoning, China
}

\section{A R T I C L E I N F O}

\section{Article history:}

Received 13 December 2016

Accepted 19 April 2017

Published 5 September 2017

\section{Keywords:}

SBA-15

Supported silver catalyst

Pretreatment condition

Competitive adsorption

Toluene oxidation

\begin{abstract}
A B S T R A C T
The catalytic oxidation of toluene over Ag/SBA-15 synthesized under different pretreatment conditions, including $\mathrm{O}_{2}$ at $500{ }^{\circ} \mathrm{C}$ (denoted 0500$), \mathrm{H}_{2}$ at $500{ }^{\circ} \mathrm{C}(\mathrm{H} 500)$, and $\mathrm{O}_{2}$ at $500{ }^{\circ} \mathrm{C}$ followed by $\mathrm{H}_{2}$ at $300{ }^{\circ} \mathrm{C}(0500-\mathrm{H} 300)$ was studied. The pretreated samples were investigated by $\mathrm{N}_{2}$ physisorption, $\mathrm{X}$-ray diffraction, and ultraviolet-visible diffuse reflectance. The pretreatment atmosphere greatly influences the status of the $\mathrm{Ag}$ and $\mathrm{O}$ species, which in turn significantly impacts the adsorption and catalytic removal of toluene. $\mathrm{Ag}_{2} \mathrm{O}$ and amorphous $\mathrm{Ag}$ particles, as well as a large amount of subsurface oxygen species, are formed on 0500, and the subsurface oxygen enhances the interaction between Ag species and toluene, so 0500 shows good activity at higher temperature. However, its activity at lower temperature is not as high as expected, with a reduced presence of $\mathrm{Ag}_{2} \mathrm{O}$ and lower adsorption capacity for toluene. $\mathrm{H}_{2}$ pretreatment at $500{ }^{\circ} \mathrm{C}$ is conducive to the formation of large $\mathrm{Ag}$ particles and yields the largest adsorption capacity for toluene, so H500 exhibits the best activity at lower temperatures; however, because of poor interaction between Ag and toluene, its activity at higher temperature is modest. The 0500-H300 sample exhibits excellent catalytic activity during the whole reaction process, which can be attributed to the small and highly dispersed Ag nanoparticles as well as the existence of subsurface oxygen.
\end{abstract}

(C) 2017, Dalian Institute of Chemical Physics, Chinese Academy of Sciences. Published by Elsevier B.V. All rights reserved.

\section{Introduction}

Volatile organic compounds (VOCs) not only are harmful to human health but also cause air pollution leading to photochemical smog, ground-level ozone, sick building syndrome, and multiple chemical sensitivity. Many techniques have been developed to eliminate VOCs in the last decades. Among various control technologies for VOC emissions, catalytic oxidation has proven particularly effective, and allows VOCs to be completely oxidized into $\mathrm{CO}_{2}$ and $\mathrm{H}_{2} \mathrm{O}$ over catalysts at much lower temperature than direct thermal oxidation [1]. One of the most targeted components among VOCs is toluene, for which the main emission sources are petroleum industries. It also has numerous local sources, such as painting, printing, and pressing. Because of the chemical stability of toluene, its complete oxidation at low temperatures is problematic with current catalytic oxidation technology [2]. Noble metals such as Pt and Pd have proven effective catalysts for toluene elimination [3-5], but the high cost of noble metal catalysts has been a severe limitation. Various transition metals (including $\mathrm{Mn}, \mathrm{Fe}, \mathrm{Co}, \mathrm{Ni}$, and $\mathrm{Cu}$ ) have been used for the toluene oxidation, but they require higher activation temperatures [6-8]. In recent years, Ag has attracted attention as an effective photocatalyst [9] and low-temperature oxidation catalyst in many reactions because

\footnotetext{
* Corresponding author. Fax: +86-411-84708083; E-mail: quzhenping@dlut.edu.cn

This work was supported by the National Natural Science Foundation of China $(21377016,21577014)$ and Program for Changjiang Scholars and Innovative Research Team in University (IRT_13R05).

DOI: 10.1016/S1872-2067(17)62842-0 | http://www.sciencedirect.com/science/journal/18722067 | Chin. J. Catal., Vol. 38, No. 9, September 2017
} 
of its high activity [10-12], better selectivity [13-15], and particular ability for the adsorption and activation of oxygen [16-18]. Ordered mesoporous silicas such as SBA-15 and MCM-41 have been considered as ideal supports for metals and metal particles $[19,20]$ because of their unique characteristics of high surface area, large pore volume, and well-defined pore size. Recently, the Ag/SBA-15 and Ag/MCM-41 catalysts have been investigated in the oxidation reactions of $\mathrm{CO}$ and $\mathrm{HCHO}$, respectively, and have displayed highly favorable activity $[21,22]$. However, less information is currently available on the performance of Ag-mesoporous silica-based catalysts for the oxidation of toluene.

It is well known that preliminary treatments have a strong influence on the structure and activity of these catalysts. The effect of pretreatment temperature has been discussed by many researchers. According to Van Steen et al. [23], higher temperatures for oxidation pretreatment lead to stronger metal-support interaction. Chen et al. [24] also observed that higher pretreatment temperatures enhanced the ability of $\mathrm{Ag}$ catalysts to form superoxide species over an activated carbon support, leading to better catalytic performance. Wang et al. [25] found that low-temperature treatment mainly affected the surface Pd species, while high-temperature treatment affected both the bulk $\mathrm{Pd}$ and $\mathrm{CeO}_{2}$, with a strong synergetic effect between metal and support. The sample pretreated at $300{ }^{\circ} \mathrm{C}$ presented the highest activity for CO oxidation and oxygen storage capacity. However, too-high pretreatment temperatures can also lead to structural changes of the active species on the catalyst [26], leading to catalyst deactivation. In addition to the pretreatment temperature, the pretreatment atmosphere is also an important factor for the structure and activity of catalysts. Kim et al. [27] found that Pt particles prepared by incipient wetness impregnation in $\mathrm{H}_{2}$ were larger than those prepared in air. Pt-Au/ZnO/ $\mathrm{Al}_{2} \mathrm{O}_{3}$ catalysts after $\mathrm{H}_{2}$ reduction at $400{ }^{\circ} \mathrm{C}$ showed higher activity for the complete oxidation of toluene. Thus, different pretreatment conditions (temperature or atmosphere) result in different states of the active sites and different forms of activity. To the best of our knowledge, at least three kinds of oxygen species (molecular, atomic, and subsurface oxygen) [28] can be adsorbed on Ag-based catalysts, and subsurface oxygen has been suggested to play a pivotal role in several catalytic reactions that are responsible for the activation of catalyst surfaces [29-31].

In the present work, the Ag/SBA-15 catalyst was synthesized by an incipient wetness impregnation method. Different pretreatment conditions, achieved by varying the pretreatment temperature and atmosphere $\left(\mathrm{O}_{2}, \mathrm{H}_{2}\right)$, were used to explore the relation between the structure of the catalyst and its catalytic activity for toluene oxidation. Moreover, the role of oxygen in the adsorption and desorption processes of toluene was also studied under different pretreatment conditions.

\section{Experimental}

\subsection{Materials and preparation}

Ag/SBA-15 catalysts were prepared by incipient wetness impregnation of $\mathrm{SBA}-15$ with $\mathrm{AgNO}_{3}$ aqueous solution (the weight loadings of Ag were $6 \%, 8 \%, 10 \%, 12 \%, 16 \%$, and $25 \%$ ) followed by drying at room temperature and then at $100{ }^{\circ} \mathrm{C}$ overnight. The series of catalysts were denoted $\operatorname{Ag}(x) /$ SBA-15 $(x=6,8,10,12,16,25)$. In order to understand the effect of different pretreatment atmospheres on the catalytic properties and structure of the catalysts, each catalyst with a given $\mathrm{Ag}$ loading were separately pretreated at $500{ }^{\circ} \mathrm{C}$ for $2 \mathrm{~h}$ in $30 \%$ $\mathrm{O}_{2} / \mathrm{Ar}$ flow (0500), $300^{\circ} \mathrm{C}$ for $1 \mathrm{~h}$ in high-purity $\mathrm{H}_{2}$ following $\mathrm{O}_{2}$ pretreatment at $500{ }^{\circ} \mathrm{C}(0500-\mathrm{H} 300)$, or $500{ }^{\circ} \mathrm{C}$ for $2 \mathrm{~h}$ in high-purity $\mathrm{H}_{2}$ (H500).

\subsection{Activity measurement}

A continuous-flow fixed-bed quartz microreactor was employed to determine the catalytic activity at atmospheric pressure for the complete oxidation of toluene. $0.1 \mathrm{~g}$ of Ag/SBA-15 catalyst was loaded into the reactor at a space velocity of 37500 $\mathrm{h}^{-1}$. The reaction stream was $1000 \mathrm{ppm}$ toluene in air with a total flow rate of $50 \mathrm{~mL} / \mathrm{min}$, and the concentration was generated by passing an Ar flow through a bottle containing pure toluene (A.R. grade) chilled in an ice-water isothermal bath. The toluene conversion was determined after 40 min reaction at each temperature using an online Agilent 7890A gas chromatograph (GC) with flame ionization detector (FID) and thermal conductivity detector (TCD).

\subsection{Characterization}

Nitrogen adsorption-desorption isotherms were measured at $-196{ }^{\circ} \mathrm{C}$ on a Quantachrome QUADRASORB-SI. Before the measurements, the samples were degassed at $110{ }^{\circ} \mathrm{C}$ for 20 min and then at $300{ }^{\circ} \mathrm{C}$ for $4 \mathrm{~h}$ under vacuum. The specific surface areas of the samples were calculated with the Brunauer-Emmett-Teller (BET) equation. The pore volumes were determined at a $p / p_{0}$ value of 0.995 . The mean pore diameters were calculated with the Barrett-Joyner-Halenda (BJH) equation from the desorption branches of the isotherms. X-ray diffraction (XRD) patterns were collected on a Rigaku D/max- $\gamma \mathrm{b}$ $(\lambda=0.1542 \mathrm{~nm})$ operated at $40 \mathrm{kV}$ and $200 \mathrm{~mA}$. Wide-angle patterns were recorded from $10^{\circ}$ to $80^{\circ}$ at a scan rate of $5 \% /$ min. The sizes of the Ag particles were calculated from the half-width of the main peak at $2 \theta=38^{\circ}$ according to Scherrer's method. Transmission electron microscopy (TEM) experiments were performed using a Tecnai G2 Spirit operated at an accelerating voltage of $100 \mathrm{kV}$. Diffuse reflectance spectra of the samples in the ultraviolet-visible (UV-vis) region were recorded using a Shimadzu UV-2450 UV-vis spectrophotometer equipped with an integrating sphere. $\mathrm{A} \mathrm{BaSO}_{4}$ disk was used as reference. All spectra were recorded under ambient conditions. An $\mathrm{O}_{2}$ temperature-programmed desorption $\left(\mathrm{O}_{2}\right.$-TPD) experiment was carried out with a mass spectrometer (Pfeiffer vacuum OmniStar GSD320). He gas was passed through the reactor and the temperature was ramped from 30 to $800{ }^{\circ} \mathrm{C}$ at a heating rate of $10{ }^{\circ} \mathrm{C} / \mathrm{min}$ and a flow rate of $50 \mathrm{~mL} / \mathrm{min}$. The effluent $\mathrm{O}_{2}(\mathrm{~m} / \mathrm{z}=32)$ from the reactor was monitored. 


\subsection{Adsorption and desorption}

Adsorption and desorption experiments were performed in a fixed-bed quartz reactor with an inner diameter of $8 \mathrm{~mm}$. The temperature was controlled by a programmable temperature controller (AI-708P). Prior to the experiments, $0.1 \mathrm{~g}$ sample (20-40 mesh) was pretreated in $\mathrm{He}$ at $300{ }^{\circ} \mathrm{C}$ for $1 \mathrm{~h}$ to remove adsorbed $\mathrm{H}_{2} \mathrm{O}$ and other gases. After cooling the catalyst, toluene adsorption was carried out in a flow of $0.1 \%$ toluene/air $\left(\mathrm{O}_{2}\right.$-rich $)$ or $0.1 \%$ toluene $/ \mathrm{He}\left(\mathrm{O}_{2}\right.$-lean $)$ with the same flow rate of $50 \mathrm{~mL} / \mathrm{min}$. Following the saturation of adsorption, as indicated by stable signals of toluene in the GC and mass spectrometer, the reactor was purged with pure He for $1 \mathrm{~h}$. For the TPD experiment, He was passed through the reactor by ramping the temperature from 30 to $400{ }^{\circ} \mathrm{C}$ at a heating rate of $10{ }^{\circ} \mathrm{C} / \mathrm{min}$ and a flow rate of $50 \mathrm{~mL} / \mathrm{min}$.

\section{Results and discussion}

\subsection{Activity for toluene oxidation}

The toluene conversion over Ag/SBA-15 catalysts with different Ag weight loadings is shown in Fig. 1. The activity increases appreciably with the Ag loading. However, $\mathrm{Ag}(16) / \mathrm{SBA}-15$ has similar activity to $\mathrm{Ag}(12) / \mathrm{SBA}-15$, and further loading increase ( $>16 \mathrm{wt} \%$ ) does not enhance the activities. To elucidate the effect of the Ag loading, the turnover frequency (TOF) for toluene oxidation was measured at $200{ }^{\circ} \mathrm{C}$ and is shown in Table 1 . The $\mathrm{Ag}(12) / \mathrm{SBA}-15$ sample displays the best activity for toluene oxidation among all the catalysts, indicating that $12 \%$ is the optimum loading to maximize the activity of Ag/SBA-15 catalysts.

Fig. 2 exhibits the toluene conversion at several reaction temperatures on the $\mathrm{Ag}(12) / \mathrm{SBA}-15$ catalysts pretreated with $\mathrm{H}_{2}$ (H500), with $\mathrm{O}_{2}(\mathrm{O} 500)$, and with $\mathrm{H}_{2}$ following $\mathrm{O}_{2}$ pretreatment (0500-H300). No steady-state activity of toluene oxidation is found for pure SBA-15 (not shown here) in our experiments, which indicates that the Ag species is the catalytic active site for toluene oxidation. As shown in this figure, the catalytic activity greatly depends on the pretreatment atmosphere and

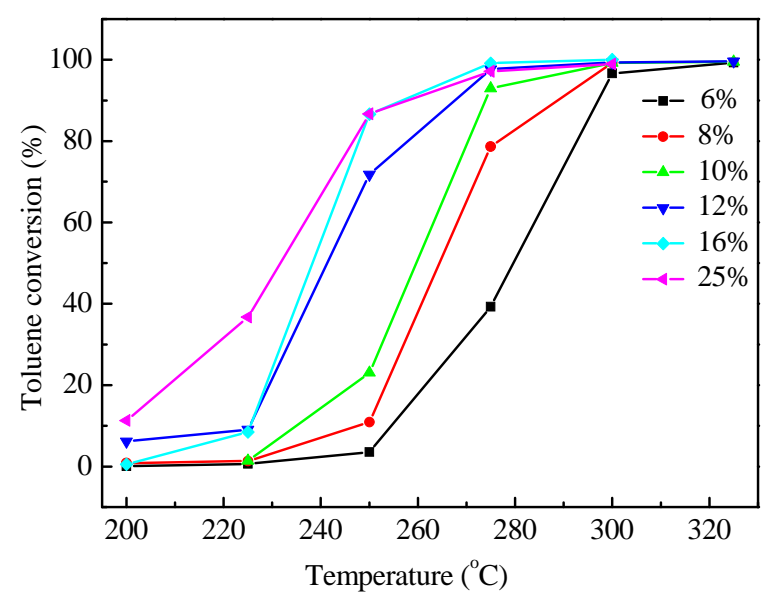

Fig. 1. Toluene conversion versus reaction temperature over $\mathrm{Ag}(x) / \mathrm{SBA}-15$ catalysts.
Table 1

TOF of toluene oxidation on $\operatorname{Ag}(x) /$ SBA-15 catalysts with different $\mathrm{Ag}$ loadings.

\begin{tabular}{lcccccc}
\hline$w(\mathrm{Ag})(\%)$ & 6 & 8 & 10 & 12 & 16 & 25 \\
\hline $\mathrm{TOF}\left(\mathrm{h}^{-1}\right)$ & 0.001 & 0.016 & 0.019 & 0.074 & 0.068 & 0.065 \\
\hline
\end{tabular}

TOF was calculated as the moles of toluene converted per mole of Ag in the entire catalyst per hour.

temperature. The temperatures required for complete conversion of toluene are different for each pretreatment condition. The activities of $\mathrm{H} 500$ and 0500 are rather low at $225^{\circ} \mathrm{C}$. With the temperature increasing to $250{ }^{\circ} \mathrm{C}$, the toluene conversion of H500 increases to about 33\% and increases further to $65 \%$ at $275{ }^{\circ} \mathrm{C}$. For the 0500 sample, the conversion at $225^{\circ} \mathrm{C}$ is low, and even at $250{ }^{\circ} \mathrm{C}$ only $13 \%$ is achieved. However, it reaches more than $90 \%$ when the temperature rises to $275^{\circ} \mathrm{C}$. The complete conversion temperature for both $\mathrm{H} 500$ and 0500 is $300{ }^{\circ} \mathrm{C}$. The $\mathrm{H} 500$ sample shows better toluene conversion at lower temperatures $\left(<260^{\circ} \mathrm{C}\right)$ than 0500 , but it does not retain this catalytic advantage when the reaction temperature is increased further. In comparison with those two samples, the conversion profile for the 0500-H300 sample shows much better performance at the lowest temperatures, with the conversion reaching almost $7 \%$ and $10 \%$ at 200 and $225{ }^{\circ} \mathrm{C}$, respectively. At $250{ }^{\circ} \mathrm{C}$, the conversion is dramatically enhanced to $70 \%$, and toluene is almost quantitatively converted at 275 ${ }^{\circ} \mathrm{C}$. In conclusion, the pretreatment atmosphere crucially affects the catalytic ability of Ag/SBA-15 catalysts. Specifically, pretreatment with $\mathrm{O}_{2}$ at $500{ }^{\circ} \mathrm{C}$ followed by $\mathrm{H}_{2}$ at $300{ }^{\circ} \mathrm{C}$ dramatically increases the activity of toluene elimination below $275^{\circ} \mathrm{C}$. Catalytic activities are commonly evaluated using the metrics $T_{10}, T_{50}$, and $T_{90}$, and their values for the three samples are summarized in Table 2 . The $T_{10}, T_{50}$, and $T_{90}$ values of 0500-H300 are 225,241 , and $276^{\circ} \mathrm{C}$, respectively, which are far more impressive than those for the other two catalysts (240, 261, and $274^{\circ} \mathrm{C}$, respectively, for 0500 , while the $T_{90}$ of $\mathrm{H} 500$ is $303^{\circ} \mathrm{C}$ ). Hence, it is clear that treatment with $\mathrm{H}_{2}$ at 300 ${ }^{\circ} \mathrm{C}$ exerts a positive effect on the ability for catalytic oxidation of toluene. The variation of catalytic activity as a function of pretreatment conditions has been suggested to be related to variation in the structure of the catalyst $[32,33]$. Table 2 also shows

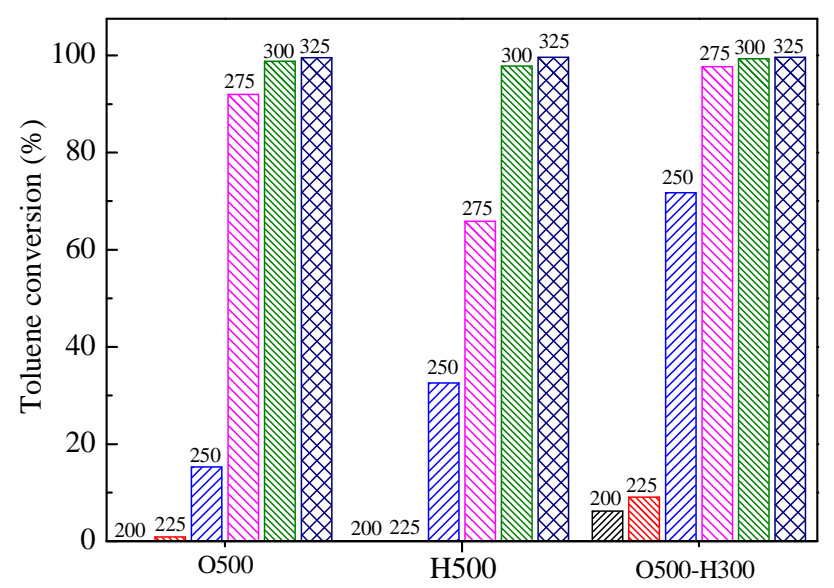

Fig. 2. Toluene conversion over Ag/SBA-15 catalysts pretreated in different atmospheres at different temperatures. 
Table 2

Catalytic activity of various catalysts for toluene oxidation.

\begin{tabular}{lccrc}
\hline Catalyst & $T_{10}\left({ }^{\circ} \mathrm{C}\right)$ & $T_{50}\left({ }^{\circ} \mathrm{C}\right)$ & $T_{90}\left({ }^{\circ} \mathrm{C}\right)$ & Ref. \\
\hline $0500-\mathrm{H} 300$ & 225 & 241 & 267 & This work \\
0500 & 240 & 261 & 274 & This work \\
$\mathrm{H} 500$ & - & 274 & 303 & This work \\
$\mathrm{Ag} / \mathrm{Al}_{2} \mathrm{O}_{3}$ & $\sim 330$ & $\sim 360$ & $\sim 380$ & {$[34]$} \\
$\mathrm{Ag} / \mathrm{CeO} 2$ & 200 & $\sim 240$ & $\sim 270$ & {$[35]$} \\
$0.81 \mathrm{Ag} / 3 \mathrm{DOM}_{2}$ & 263 & 308 & 338 & {$[36]$} \\
$26.9 \mathrm{CeO}_{2}-\mathrm{Al}_{2} \mathrm{O}_{3}$ & & & &
\end{tabular}

$T_{10}, T_{50}$, and $T_{90}\left({ }^{\circ} \mathrm{C}\right)$ : the temperatures at which conversion reaches $10 \%, 50 \%$, and $90 \%$, respectively.

[34]: concentration $1000 \mathrm{ppm}$, flow rate $100 \mathrm{~mL} / \mathrm{min}$, catalyst $0.2 \mathrm{~g}$.

[35]: concentration $2000 \mathrm{ppm}$, flow rate $100 \mathrm{~mL} / \mathrm{min}$, catalyst $0.1 \mathrm{~g}$.

[36]: concentration $1000 \mathrm{ppm}$, flow rate $16.7 \mathrm{~mL} / \mathrm{min}$, catalyst $0.05 \mathrm{~g}$.

the catalytic activities of several other Ag-based catalysts. For $\mathrm{Ag} / \mathrm{Al}_{2} \mathrm{O}_{3}, T_{10}$ is roughly $330{ }^{\circ} \mathrm{C}$ and $T_{90}$ is about $380{ }^{\circ} \mathrm{C}$ [34]. An Ag catalyst supported on $\mathrm{CeO}_{2}$ showed good performance for toluene oxidation, with a $T_{90}$ of $270{ }^{\circ} \mathrm{C}$ [35], while the $T_{10}$ and $T_{90}$ of Ag supported on three-dimensional ordered macroporou (3DOM) $\mathrm{CeO}_{2}-\mathrm{Al}_{2} \mathrm{O}_{3}$ were 263 and $338{ }^{\circ} \mathrm{C}$ [36]. Therefore, 0500-H300 shows highly competitive activity and outperforms several other Ag-based catalysts, indicating the importance of the pretreatment atmosphere and temperature.

\subsection{Catalyst characterization}

To examine the influence of pretreatment atmosphere on the properties of the Ag-based catalyst, the nitrogen adsorption-desorption isotherms were used to obtain textural information on the parent and pretreated catalysts. As shown in Fig. 3, the isotherms for SBA-15 and Ag/SBA-15 are of type IV and exhibit a hysteresis loop of type $\mathrm{H} 1$ according to the IUPAC classification, which indicates that the parent mesoporous structure was well maintained during the synthesis. The pore structure parameters of all the samples are summarized in Table 3. No major textural changes are found between the parent and the modified samples. The BET surface areas of the modified samples clearly decrease, but no change in the pore diameter of the SBA-15 sample after the impregnation procedure is observed, indicating that most of the metal species is

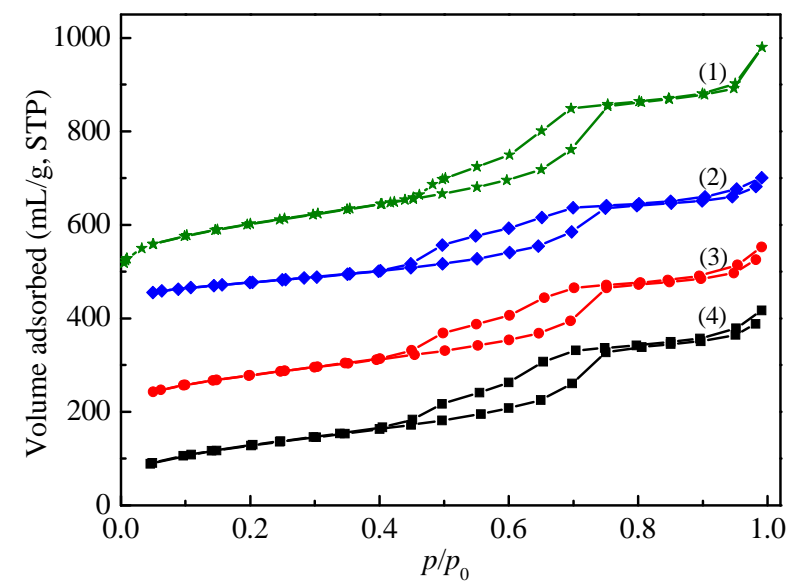

Fig. 3. $\mathrm{N}_{2}$ adsorption-desorption isotherms of parent SBA-15 (1) and Ag/SBA-15 pretreated with $\mathrm{O}_{2}(2), \mathrm{H}_{2}(3)$, and $\mathrm{O}_{2} / \mathrm{H}_{2}$ (4).
Table 3

Pore structure parameters of SBA-15 and Ag/SBA-15 samples derived from the $\mathrm{N}_{2}$ adsorption-desorption isotherms.

\begin{tabular}{lccccc}
\hline Sample & $\begin{array}{c}S_{\text {multi }} \\
\left(\mathrm{m}^{2} / \mathrm{g}\right)\end{array}$ & $\begin{array}{c}V_{\text {total }} \\
\left(\mathrm{cm}^{3} / \mathrm{g}\right)\end{array}$ & $\begin{array}{c}D_{\text {pore }}{ }^{\mathrm{a}} \\
(\mathrm{nm})\end{array}$ & $\begin{array}{c}V^{\mathrm{b}} \\
(\mathrm{mg} / \mathrm{g})\end{array}$ & $\begin{array}{c}V^{\mathrm{c}} \\
(\mathrm{mg} / \mathrm{g})\end{array}$ \\
\hline SBA-15 & 596.0 & 0.842 & 5.63 & 73.9 & 76.5 \\
O500-H300 & 483.1 & 0.655 & 5.62 & 51.2 & 50.5 \\
0500 & 284.3 & 0.470 & 5.62 & 61.4 & 76.0 \\
H500 & 469.4 & 0.630 & 5.62 & 67.3 & 90.4 \\
\hline
\end{tabular}

${ }^{\mathrm{a}} D_{\text {pore, }} \mathrm{BJH}$ mesopore diameter calculated from the desorption branch.

${ }^{b}$ Breakthrough capacity for toluene under $\mathrm{O}_{2}$-rich condition.

${ }^{\mathrm{c}}$ Breakthrough capacity for toluene under $\mathrm{O}_{2}$-lean condition.

located on the outer surface of the support. The large loss of surface area for the 0500 sample is probably caused by the agglomeration of $\mathrm{Ag}$ species on the surface or by the nanoparticles' blocking the space after $\mathrm{O}_{2}$ pretreatment at $500{ }^{\circ} \mathrm{C}$.

To further characterize the status of the Ag species after different pretreatments, the wide-angle XRD patterns for the three samples are shown in Fig. 4. In the patterns of the H500 and 0500-H300 samples, four Ag diffraction peaks can be seen at $2 \theta=38.0^{\circ}, 44.3^{\circ}, 64.4^{\circ}$, and $77.6^{\circ}$, which correspond to the (111), (200), (220), and (311) lattice planes of the structure of Ag, respectively (JCPDS card, File No.46-1043). A very broad signal is also seen at $2 \theta=22.43^{\circ}$ for amorphous silica. Thus, metallic Ag is the main species on the $\mathrm{H} 500$ and $0500-\mathrm{H} 300$ samples. In the present work, no obvious peaks for metal Ag particles are detected for the 0500 sample: only a small $\mathrm{Ag}_{2} \mathrm{O}$ peak appears at $2 \theta=33^{\circ}$. Thus, it is suggested that Ag might exist as highly dispersed particles or as an amorphous species that cannot be detected by XRD. Combined with the $\mathrm{N}_{2}$ adsorption-desorption results, the catalyst pretreated with $\mathrm{O}_{2}$ shows the lowest surface area $\left(S_{\text {Multi }}\right)$ and a relatively low pore volume ( $\left.V_{\text {total }}\right)$, indicating that Ag probably exists as an amorphous species with large particle size [37]. In the Ag catalyst pretreated with $\mathrm{H}_{2}$ at $500{ }^{\circ} \mathrm{C}$, most of the $\mathrm{Ag}$ is in the metallic state, and the Ag diffraction peak at $38.0^{\circ}$ is markedly intensified, which can be attributed to the aggregation of Ag into large particles. As calculated from the half-width of the Ag peak in the XRD pattern, the particle size is about $11.4 \mathrm{~nm}$ for the $\mathrm{H} 500$ sample. For

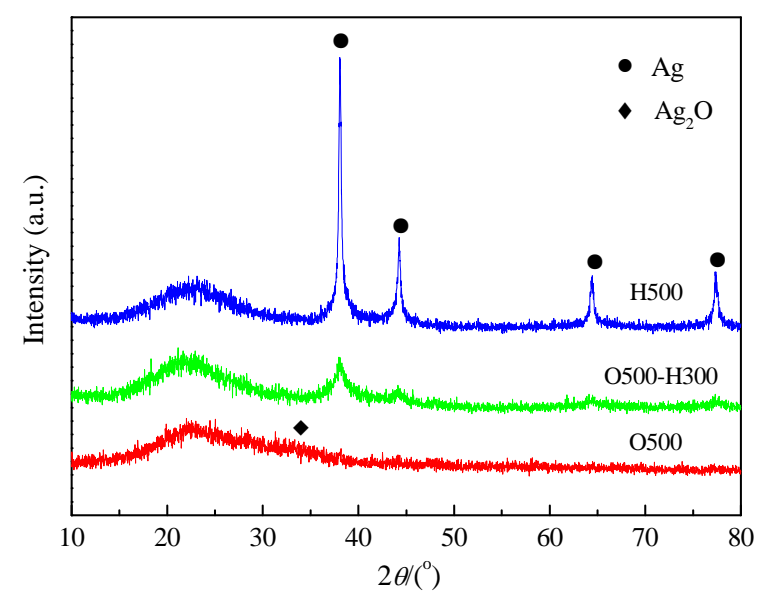

Fig. 4. XRD patterns of the samples pretreated under different conditions. 

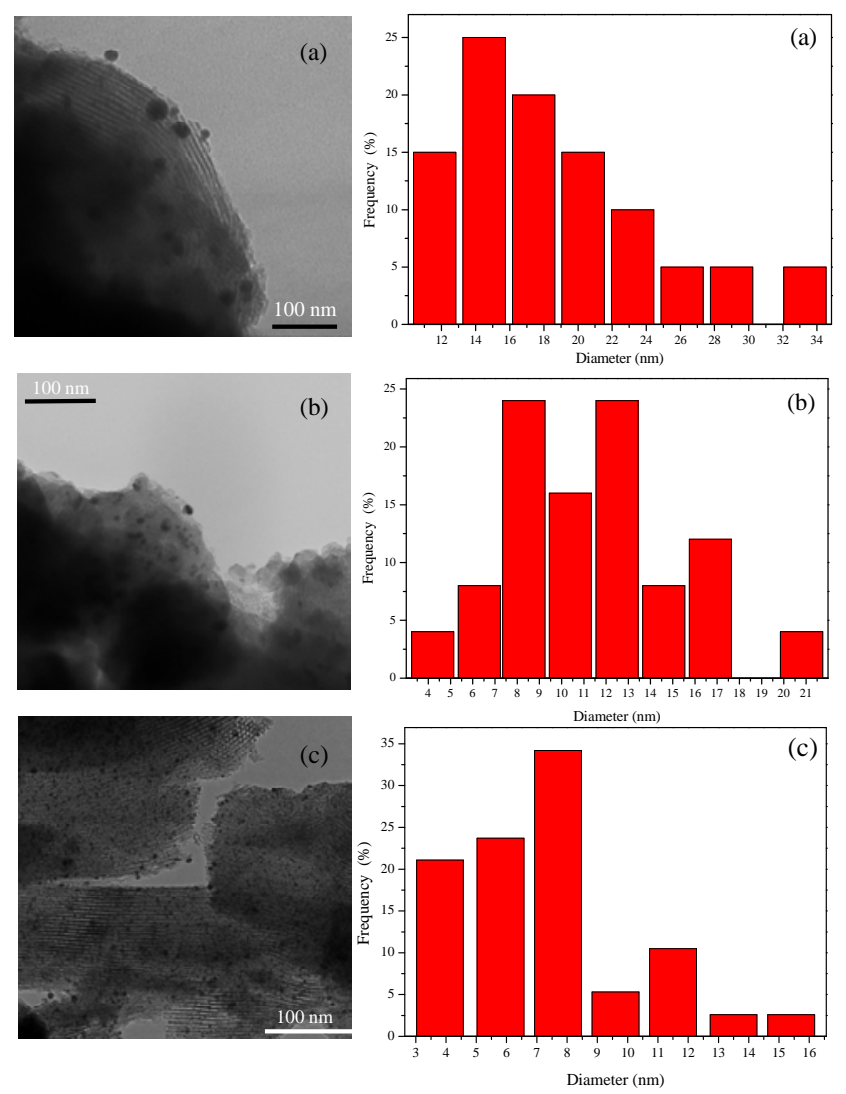

Fig. 5. TEM images and particle size distributions of O500 (a); H500 (b) and $0500-\mathrm{H} 300(\mathrm{c})$.

the sample in which $\mathrm{Ag}$ was further treated in $\mathrm{H}_{2}$ atmosphere at $300{ }^{\circ} \mathrm{C}$ following $\mathrm{O}_{2}$ pretreatment at $500{ }^{\circ} \mathrm{C}$, the diffraction peaks corresponding to $\mathrm{Ag}_{2} \mathrm{O}$ disappear. At the same time, $\mathrm{Ag}$ diffraction peaks appear, and are lower and broader than in the H500 sample. Meanwhile, the surface area of 0500-H300 is larger than that of 0500, indicating that the Ag particles are smaller and are redispersed on the support surface. Fig. 5 shows the TEM images and the particle size distribution of the samples. The particle sizes of 0500 range from 10 to $33 \mathrm{~nm}$, while those of $\mathrm{H} 500$ have sizes of 3-20 nm. The particles of 0500-H300 are the most homogeneous of the three samples. The average diameters for the three samples are 18.6, 11.3, and $7.3 \mathrm{~nm}$, respectively. Thus, it is reasonable to suggest that the high activity for toluene oxidation is related to the thorough dispersion of Ag particles after $\mathrm{H}_{2}$ reduction. Though $\mathrm{H} 500$ shows similar surface physical properties (Table 3) to 0500-H300, its catalytic activity is lower, which we propose is closely associated with the $\mathrm{Ag}$ particle size and the structure of the Ag species.

UV-vis spectroscopy (Fig. 6) was used to investigate the characteristics of the Ag nanoparticles in the mesoporous silica matrix after the different pretreatments. Two bands are observed in the 0500 sample. The band at $220 \mathrm{~nm}$ can be assigned to the $4 d^{10}$ to $4 d^{9} s^{1}$ transition of $\mathrm{Ag}^{+}$ions, and the weak band at $430 \mathrm{~nm}$ is characteristic of metallic Ag particles [13, 38]. Compared with the 0500 catalyst, the band for $\mathrm{H} 500$ at about $380 \mathrm{~nm}$ is more intense, and contains two peaks at 375 and $430 \mathrm{~nm}$, as shown in Fig. 6(b). Keshavaraja et al. [39] reported that the band at $350 \mathrm{~nm}$ was assigned to $\mathrm{Ag}_{n}{ }^{\delta+}$, and disappeared as the Ag loading increased. Hence, in this work, the formation of $\mathrm{Ag}_{n}{ }^{\delta+}$ on $\mathrm{H} 500$ was also very slight because of the high Ag loading (12\%), and the peak at $375 \mathrm{~nm}$ is more likely to be assigned to metallic Ag. On the basis of Mie's theory [40], spherical Ag nanoparticles should give a single symmetric absorption band around $410 \mathrm{~nm}$, whereas anisotropic nanoparticles should exhibit two or more bands. In addition, at about 276 $\mathrm{nm}$ a broad absorption band appears, indicating the formation of $\mathrm{Ag}_{n}$ clusters on $\mathrm{H} 500$ [41]. When the catalyst pretreated with $\mathrm{O}_{2}$ at $500{ }^{\circ} \mathrm{C}$ was further reduced with $\mathrm{H}_{2}$ at $300{ }^{\circ} \mathrm{C}$, the band at $430 \mathrm{~nm}$ redshifted to higher wavelength (453 nm), which indicates that the $\mathrm{Ag}^{0}$ particles became smaller. The corresponding peak was also broader and more intense in comparison with $\mathrm{O} 500$ and H500. This means that a high concentration of $\mathrm{Ag}^{0}$ was formed, suggesting the reduction of the $\mathrm{Ag}_{2} \mathrm{O}$ species to small Ag particles after pretreatment with $\mathrm{H}_{2}$ at $300{ }^{\circ} \mathrm{C}$ (Fig. 6(a)). To investigate the stability of the samples, a used sample of H500 was also investigated by UV-vis spectroscopy. The spectrum of the used sample is almost identical to that of the fresh one, indicating that the properties of the samples were unchanged during the reaction (Fig. 6(c)).

\subsection{Dynamic adsorption and temperature-programmed desorption of toluene}

For the process of catalysis, first, reactant and $\mathrm{O}_{2}$ molecules are diffused on and into the catalyst. Then, they are adsorbed onto the active site and activated. Finally, a chemical reaction takes place and the products are desorbed. The competitive
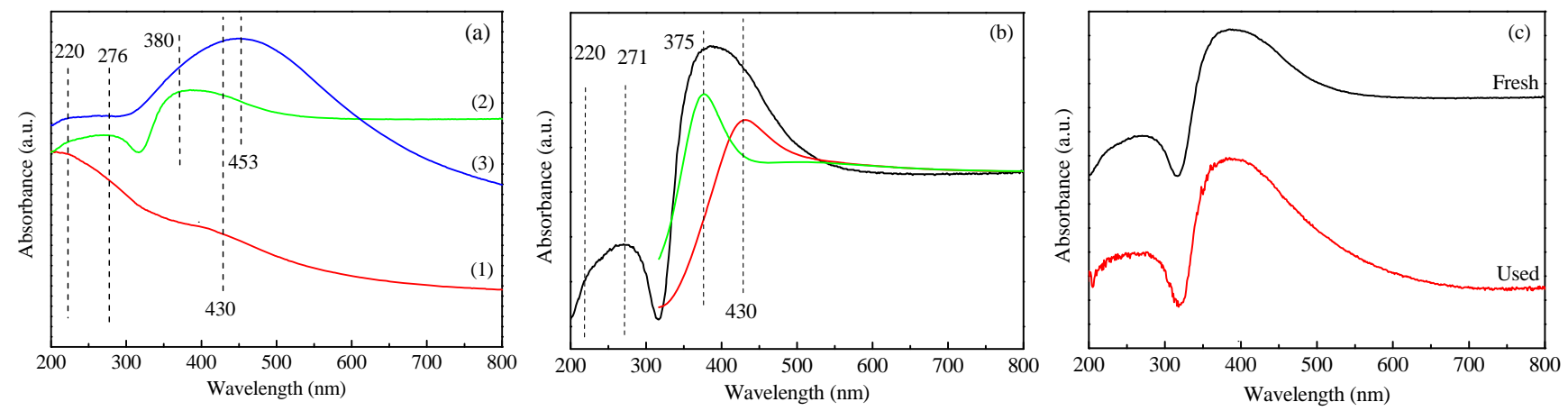

Fig. 6. (a) UV-vis spectra of 0500 (1), H500 (2), and O500-H300 (3); (b) UV-vis spectra of H500; (c) UV-vis spectra of H500: fresh and after reaction at $270{ }^{\circ} \mathrm{C}$. 

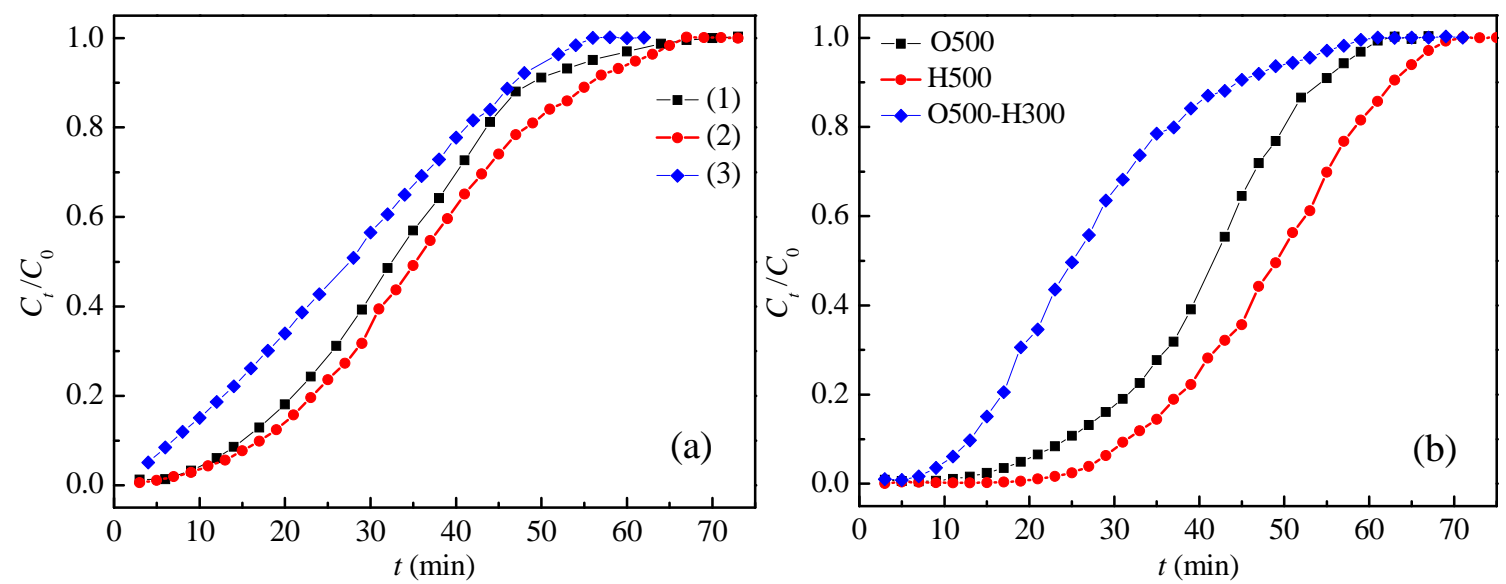

Fig. 7. Adsorption breakthrough curves of toluene over 0500 (1), $\mathrm{H} 500$ (2), and 0500-H300 (3) samples. (a) $\mathrm{O}_{2}$-rich; (b) $\mathrm{O}_{2}$-lean.

adsorption between reactants and $\mathrm{O}_{2}$, and the adsorption capability of the catalyst, are crucially related to its catalytic activity. Hence, it is essential to study the adsorption capability of catalysts, especially in the presence or absence of $\mathrm{O}_{2}$.

Fig. 7 shows the toluene adsorption breakthrough curves under the $\mathrm{O}_{2}$-lean and $\mathrm{O}_{2}$-rich conditions at room temperature over Ag/SBA-15 samples prepared with different pretreatments. First, the parent material SBA-15 was studied, to broaden our understanding of the adsorption characteristics of toluene on different samples, as shown in Table 3. For the bare SBA-15 support, no obvious change was observed for the breakthrough capacity for toluene adsorption under either of the $\mathrm{O}_{2}$ conditions. That is to say, no competitive adsorption takes place between $\mathrm{O}_{2}$ and toluene on SBA-15. When an $\mathrm{Ag}$ species is supported on the SBA-15, the adsorption capacity is greatly enhanced. Under both conditions, the adsorption capacities can be clearly ranked in the following order: H500 > 0500 $>$ 0500-H300; however, the capacities of the catalysts vary greatly depending on the presence or absence of $\mathrm{O}_{2}$. Under the $\mathrm{O}_{2}$-lean condition, the capacity of $\mathrm{H} 500$ is $90.4 \mathrm{mg} / \mathrm{g}$, which is 1.19 and 1.79 times those of the 0500 and 0500-H300 samples, respectively. An Ag-Y zeolite has also been reported to offer particularly high adsorption capacity via specific interactions $[42,43]$. When toluene is adsorbed together with $\mathrm{O}_{2}\left(\mathrm{O}_{2}\right.$-rich), the capacity of $\mathrm{H} 500$ falls to $67.3 \mathrm{mg} / \mathrm{g}$, while that of 0500 falls

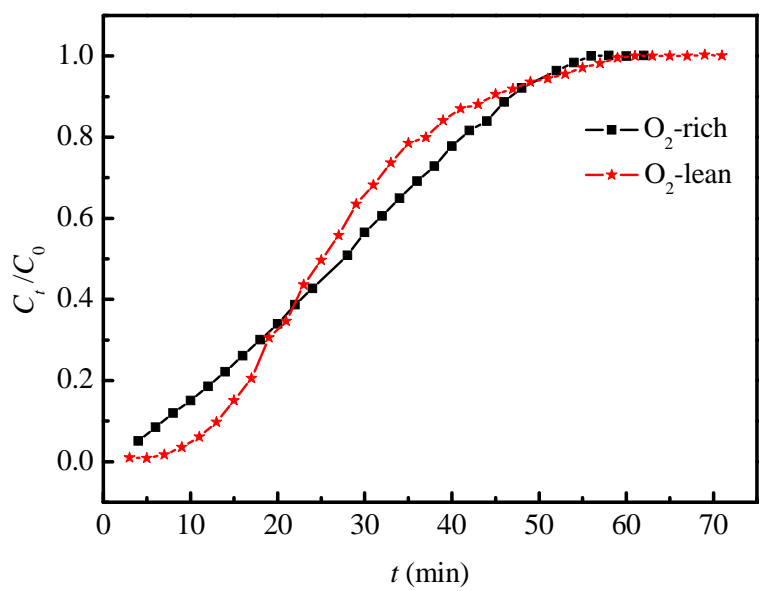

Fig. 8. Adsorption breakthrough curves of toluene over 0500-H300 sample under $\mathrm{O}_{2}$-rich and $\mathrm{O}_{2}$-lean conditions. slightly to $61.4 \mathrm{mg} / \mathrm{g}$. The significant reduction in capacity results from the shorter breakthrough time (Fig. 7(b)). However, 0500-H300 continues to display a similar capacity to that under the $\mathrm{O}_{2}$-lean condition, indicating that the presence of $\mathrm{O}_{2}$ has little influence on the toluene adsorption capacity of 0500-H300, unlike the $\mathrm{H} 500$ and 0500 samples. Comparing the two breakthrough curves of 0500-H300, it is observed that in the absence of $\mathrm{O}_{2}$, the breakthrough time is longer, and after breakthrough the concentration of toluene returns to its initial value faster than under the $\mathrm{O}_{2}$-rich condition (Fig. 8).

TPD was used to obtain information about the surface-adsorbed species and surface reactions. To investigate the surface properties of the pretreated samples, temperature ramping was carried out following adsorption of toluene under the $\mathrm{O}_{2}$-rich condition at a range of temperatures, using $\mathrm{He}$ as the carrier gas. Fig. 9 shows the toluene TPD profiles of the Ag-based catalysts pretreated under different conditions, with the data for bare SBA-15 also presented for comparison. In all the TPD experiments, the temperature was ramped at 10 ${ }^{\circ} \mathrm{C} / \mathrm{min}$ to a final value of $400{ }^{\circ} \mathrm{C}$ with a He flow rate of 50 $\mathrm{mL} / \mathrm{min}$. As shown in Fig. 9, each sample exhibits a peak at about $100^{\circ} \mathrm{C}$, with varying peak areas. Among the four samples, 0500 has the largest peak area and H500 the smallest, meaning there is no strict correspondence between peak area and adsorption capacity and that toluene interacts more strongly with

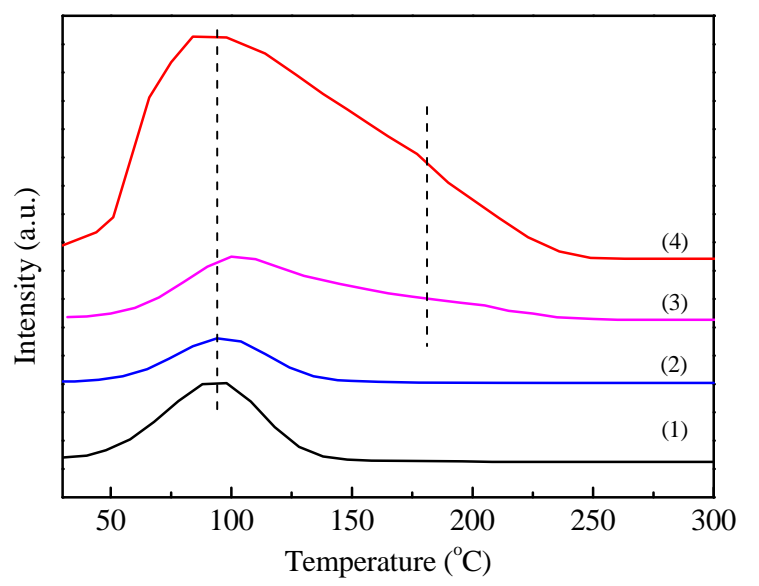

Fig. 9. Temperature-programmed desorption of toluene over SBA-15 (1), H500 (2), 0500-H300 (3), and 0500 (4). 
0500 than with H500. In addition, while H500 has only one desorption peak, for the 0500 and 0500-H300 samples another peak at about $180{ }^{\circ} \mathrm{C}$ appears, and a broader desorption window is observed at the temperature range of $100-250^{\circ} \mathrm{C}$. Since no peaks above $100^{\circ} \mathrm{C}$ are observed for SBA-15, one can conclude that the toluene desorbed at higher temperatures is bonded to Ag adsorption sites. In this work, the area of the peak at about $100{ }^{\circ} \mathrm{C}$ is notably smaller for $\mathrm{H} 500$ than that of the support, even though the adsorption capacity of H500 is the largest among all the samples.

Different pretreatments signally influence the structure of $\mathrm{Ag} / \mathrm{SBA}-15$ with respect to the state and particle size of the $\mathrm{Ag}$ species. Under $\mathrm{H}_{2}$ pretreatment at $500{ }^{\circ} \mathrm{C}$, large Ag particles are formed, while on $0500, \mathrm{Ag}_{2} \mathrm{O}$ particles coexist with $\mathrm{Ag}$ particles. $\mathrm{H}_{2}$ pretreatment at $300{ }^{\circ} \mathrm{C}$ followed by $\mathrm{O}_{2}$ at $500{ }^{\circ} \mathrm{C}$ fully reduces the $\mathrm{Ag}_{2} \mathrm{O}$ content to $\mathrm{Ag}$, and the $\mathrm{Ag}$ particles become smaller. These differences among the catalysts directly affect their adsorption and catalytic ability for toluene.

The study of dynamic adsorption indicated that the adsorption capacity of the catalysts for toluene follows the order: $\mathrm{H} 500>0500>0500-\mathrm{H} 300$ under both the $\mathrm{O}_{2}$-lean and $\mathrm{O}_{2}$-rich conditions. It is well known that high surface area is an essential contributory factor in achieving a large dynamic capacity for silica-based adsorbents [44]. However, in this study, the 0500 sample exhibits lower surface $\left(S_{\text {Multi }}\right)$ and pore volumes $\left(V_{\text {total }}\right)$ than the other samples, while its adsorption capacity is much higher than 0500-H300. Hence, the adsorption ability of these modified samples is no longer simply related to their surface physical nature, and the supported metallic species also exert a significant effect on the adsorption capacity compared with the bare SBA-15 support. In this work, the H500 sample, with a metallic surface state, shows a better adsorption capacity than the 0500 and $0500-\mathrm{H} 300$ samples, especially under the $\mathrm{O}_{2}$-lean condition. Some researchers have noted that the reduced state of Pd was more favorable than the oxidized form for the adsorption of VOCs, which was related to the existence of Lewis acid sites in the support and the interaction of the reduced metal with the support [45-47]. However, the 0500-H300 sample also clearly contains Ag in the reduced state (Fig. 4 and Fig. 6), yet its adsorption capacity $(50.5 \mathrm{mg} / \mathrm{g}$ in the $\mathrm{O}_{2}$-lean condition) is much lower than the $\mathrm{H} 500$ sample ( $90.4 \mathrm{mg} / \mathrm{g})$; this may be attributed to the different sizes of the $\mathrm{Ag}$ nanoparticles. The $\mathrm{Ag}^{0}$ particles located on the 0500-H300 sample are small and highly dispersed, which seems to disfavor the adsorption capability.

In the $\mathrm{O}_{2}$-rich condition, the breakthrough adsorption capacities for $\mathrm{H} 500$ and 0500 are lower than in the $\mathrm{O}_{2}$-lean condition, with an especially sharp decrease for the H500 sample. It is known from Table 3 that no competitive adsorption occurs on the SBA-15 support, so the difference in the capacities in the presence or absence of $\mathrm{O}_{2}$ must be closely related to the $\mathrm{Ag}$ species. The results imply that $\mathrm{O}_{2}$ competes strongly with toluene for adsorption on large $\mathrm{Ag}$ species: in this case, $\mathrm{O}_{2}$ is adsorbed on Ag in preference to toluene and occupies the same adsorption sites, so that adsorption saturation is reached fast and the breakthrough time becomes short. Thus, we can conclude that $\mathrm{O}_{2}$ is more easily adsorbed on the samples in the combined presence of toluene and $\mathrm{O}_{2}$, and the presence of $\mathrm{O}_{2}$ on the adsorption sites inhibits the adsorption of toluene. Although 0500-H300 has the smallest breakthrough adsorption capacity under the $\mathrm{O}_{2}$-lean condition, the reduction in capacity is minimal in the presence of $\mathrm{O}_{2}$. This implies that small, highly dispersed Ag particles have a greater affinity for toluene than large Ag particles, while their adsorption capacity is unaffected.

It has been shown that the adsorption affinities of metallic sites were 5-620 times larger than those of the support, and that toluene was more strongly adsorbed on metallic sites than on the support regardless of the pretreatment methods [48]. In our results, it is clear that the areas of the desorption peaks do not follow the same order as the capacities of the samples. 0500 shows the largest desorption peak of toluene, indicating that this sample has the strongest interaction with the target pollutant. Though $\mathrm{H} 500$ has the best adsorption capacity, 67.3 $\mathrm{mg} / \mathrm{g}$, its desorption peak in the TPD experiment is the smallest of all the samples, which probably indicates that most of the toluene was actually removed during the purge process, while the affinity of this sample for toluene is relatively weak. In addition, 0500 and 0500-H300 display two desorption peaks, in contrast to $\mathrm{H} 500$ and the SBA-15 support, which have only one. This shows that $\mathrm{O}_{2}$ pretreatment exerts some direct effect on the adsorption capability. Reports are prevalent in the literature that $\mathrm{O}_{2}$ pretreatment of Ag-based catalysts leads to the formation of subsurface oxygen species, and oxygen located near the surface can alter the adsorption properties of surface Ag atoms [49]. In this study, $\mathrm{O}_{2}$-TPD was performed only on the 0500 and 0500-H300 samples, since no subsurface oxygen was observed in the catalysts pretreated with $\mathrm{H}_{2}$ at $500{ }^{\circ} \mathrm{C}$ [30]. From Fig. 10, the presence of oxygen species in both the 0500 and 0500-H300 samples is clear, implying that both samples contain subsurface oxygen. It is known that the chemisorption energy increases considerably if subsurface oxygen is present, and this is correlated with a stronger hybridization between $\mathrm{Ag}$ and toluene [50]. This effect is caused by the electronegative oxygen atoms, which induce a positive charge on neighboring Ag atoms, thus strengthening their interaction with the toluene-oxygen system. Combined with the result of the adsorption-desorption study, it is evident that the subsurface oxygen species contribute to enhancing the toluene adsorption affini-

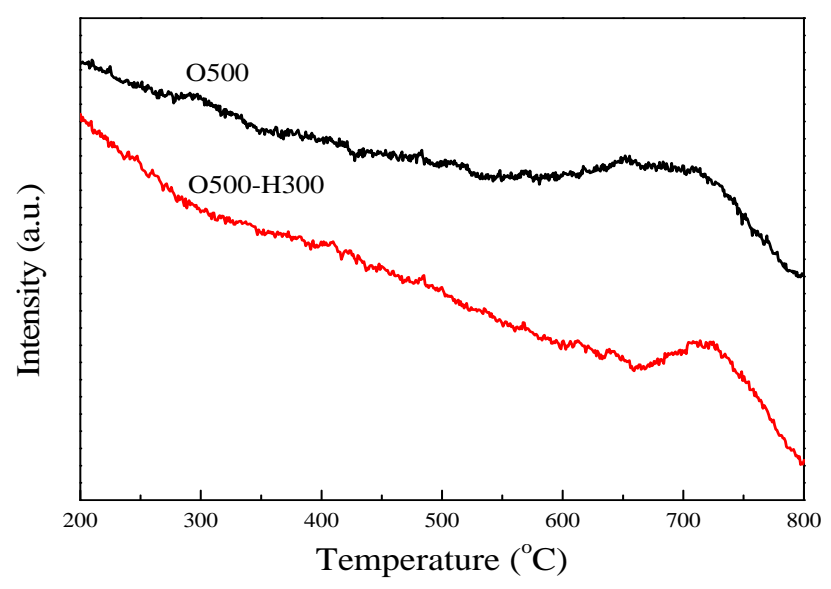

Fig. 10. $\mathrm{O}_{2}$ TPD profiles of 0500 and $0500-\mathrm{H} 300$ samples. 
ties of the $\mathrm{O}_{2}$-treated samples. After low-temperature pretreatment with $\mathrm{H}_{2}$, the surface structure of the catalyst is not completely destroyed, so that subsurface oxygen species remain present in 0500-H300, as shown in Fig. 10. This may be why the high-temperature desorption peak does not disappear in the sample pretreated with $\mathrm{H}_{2}$ at low temperature.

It has been reported that subsurface oxygen species importantly affect the catalytic activity in different reactions on $\mathrm{Ag}$ catalysts. In this paper, it is observed that at temperatures under $260{ }^{\circ} \mathrm{C}, \mathrm{H} 500$ shows better activity than 0500, probably because of its greater adsorption capacity for toluene; however, because of the lack of subsurface oxygen in H500, at higher temperatures toluene is easily desorbed because of the weakness of the interaction between toluene and $\mathrm{Ag}$ particles, so the activity of $\mathrm{H} 500$ is poor above $260{ }^{\circ} \mathrm{C}$. By contrast, the activity of 0500 is superior to $\mathrm{H} 500$ at higher temperatures $\left(>260{ }^{\circ} \mathrm{C}\right)$ because of the presence of subsurface oxygen, which enhances the interaction of toluene with Ag. According to XRD, a small number of $\mathrm{Ag}_{2} \mathrm{O}$ particles are formed on 0500. This might imply that at lower temperatures $\left(<260^{\circ} \mathrm{C}\right)$, metallic Ag tends to improve the catalytic activity against toluene while $\mathrm{Ag}_{2} \mathrm{O}$ has a negative effect on the activity. Meanwhile, 0500-H300 shows the best activity against toluene despite having less subsurface oxygen species than 0500, which implies that high activity is caused by additional factors besides subsurface oxygen. The high-temperature $\mathrm{O}_{2}$ treatment of 0500-H300 induces the faceting of the Ag surface to high-index planes, while the subsequent reduction by $\mathrm{H}_{2}$ at low temperature redisperses the $\mathrm{Ag}$ particles and results in a greater number of Ag particles with smaller sizes, as evidenced by the XRD results. The small size of the particles promotes their interaction with toluene. Besides this, the activation of $\mathrm{O}_{2}$ is a crucial factor in catalytic reactions, and occurs more easily on smaller Ag particles [51]. Hence, 0500-H300 gives an outstanding performance for toluene catalytic oxidation compared with the catalysts in which Ag is not redispersed. In summary, we conclude that small, redispersed Ag particles and subsurface oxygen are the key factors promoting catalytic activity of toluene oxidation.

\section{Conclusions}

This study revealed that different pretreatment conditions greatly affect the structure of Ag-based catalysts and in turn their adsorption capability and catalytic activity against toluene. The BET, XRD, UV-vis, and $\mathrm{O}_{2}$-TPD results showed that different pretreatments led to different effects on the formation of both $\mathrm{Ag}$ and $\mathrm{O}$ species on the $\mathrm{Ag} / \mathrm{SBA}-15$ catalyst. Under $\mathrm{H}_{2}$ pretreatment at $500{ }^{\circ} \mathrm{C}$, large $\mathrm{Ag}$ particles are formed on the support. $\mathrm{O}_{2}$ pretreatment at $500{ }^{\circ} \mathrm{C}$ leads to the formation of both $\mathrm{Ag}$ and $\mathrm{Ag}_{2} \mathrm{O}$, while $\mathrm{H}_{2}$ treatment at $300{ }^{\circ} \mathrm{C}$ followed by $\mathrm{O}_{2}$ pretreatment at $500{ }^{\circ} \mathrm{C}$ leads to the reduction of $\mathrm{Ag}_{2} \mathrm{O}$ and redispersion of $\mathrm{Ag}$, resulting in smaller Ag particles. The different $\mathrm{Ag}$ species directly influence the adsorption capacity for toluene. The large $\mathrm{Ag}$ particles formed by $\mathrm{H}_{2}$ pretreatment at $500^{\circ} \mathrm{C}$ endow the resulting catalyst with the largest adsorption capacity, which contributes to its good performance at lower temperatures. However, because of the lack of oxygen species, its affinity for toluene on $\mathrm{Ag}$ is poor, resulting in poor activity when raising the temperature. In the sample formed through $\mathrm{O}_{2}$ pretreatment at $500{ }^{\circ} \mathrm{C}$, which contains both amorphous $\mathrm{Ag}$ particles and $\mathrm{Ag}_{2} \mathrm{O}$ particles, the activity at lower temperature is hindered because of the reduced adsorption capacity and the existence of $\mathrm{Ag}_{2} \mathrm{O}$; however, the higher-temperature activity is better than that of H500, which is attributed to the existence of subsurface oxygen species, which increase the affinity between toluene and Ag, thus facilitating the reaction. On 0500-H300, the Ag particles are redispersed and smaller, which does not directly benefit the adsorption capacity for toluene. However, the smaller Ag particles have a greater affinity for toluene, as well as being able to activate $\mathrm{O}_{2}$ more easily, so that the activity of 0500-H300 at lower temperatures is remarkably high. As this sample retains the subsurface oxygen species, which strengthens the interaction between toluene and $\mathrm{Ag}$, at higher temperatures the 0500-H300 catalyst still retains good activity. In summary, the subsurface oxygen species and smaller, dispersed Ag particles on 0500-H300 endow it with higher activity than the 0500 and H500 samples.

\section{References}

[1] S. W. Baek, J. R. Kim, S. K. Ihm, Catal. Today, 2004, 93-95, 575-581.

[2] T. Masui, H. Imadzu, N. Matsuyama, N. Imanaka, J. Hazard. Mater, 2010, 176, 1106-1109.

[3] J. Bedia, J. M. Rosas, J. Rodriguez-Mirasol, T. Cordero, Appl. Catal. B, 2010, 94, 8-18.

[4] X. R. Fu, Y. Liu, W. Y. Yao, Z. B. Wu, Catal. Commun., 2016, 83, 22-26.

[5] H. G. Yang, J. G. Deng, Y. X. Liu, S. H. Xie, P. Xu, H. X. Dai, Chin. J. Catal., 2016, 37, 934-946.

[6] D. Chlala, J. M. Giraudon, N. Nuns, C. Lancelot, R. N. Vannier, M. Labaki, J. F. Lamonier, Appl. Catal. B, 2016, 184, 87-95.

[7] F. Wang, H. X. Dai, J. G. Deng, S. H. Xie, H. G. Yang, W. Han, Chin. J. Catal., 2014, 35, 1475-1481.

[8] B. Z. Gao, J. G. Deng, Y. X. Liu, Z. X. Zhao, X. W. Li, Y. Wang, H. X. Dai, Chin. J. Catal., 2013, 34, 2223-2229.

[9] X. D. Zhang, Y. X. Wang, F. L. Hou, H. X. Li, Y. Yang, Y. Q. Yang, Y. Wang, Appl. Surf. Sci., 2017, 476-483.

[10] X. D. Zhang, H. Dong, Y. Wang, N. Liu, Y. H. Zuo, L. F. Cui, Chem. Eng. J., 2016, 283, 1097-1107.

[11] H. L. Jiang, T. Akita, T. Ishida, M. Haruta, Q. Xu, J. Am. Chem. Soc., 2011, 133, 1304-1306.

[12] L. Zhang, F. D. Liu, Y. B. Yu, Y. C. Liu, Zhang, C. B. He Hong, Chin. J. Catal., 2011, 32, 727-735.

[13] L. Zhang, C. B. Zhang, H. He, J. Catal., 2009, 261, 101-109.

[14] Q. Wu, H. W. Gao, H. He, Chin. J. Catal., 2006, 27, 403-408.

[15] L. Ma, L. H. Jia, X. F. Guo, L. J. Xiang, Chin J. Catal., 2014, 35, 108-119.

[16] V. Zielasek, B. Jürgens, C. Schulz, J. Biener, M. M. Biener, A. V. Hamza, M. Bäumer, Angew. Chem. Int. Ed., 2006, 45, 8241-8244.

[17] A. Wittstock, B. Neumann, A. Schaefer, K. Dumbuya, C. Kübel, M. M. Biener, V. Zielasek, H. P. Steinrück, J. M. Gottfried, J. Biener, A. Hamza, M. Bäumer, J. Phys. Chem. C, 2009, 113, 5593-5600.

[18] C. X. Xu, J. X. Su, X. H. Xu, P. P. Liu, H. J. Zhao, F. Tian, Y. Ding, J. Am. Chem. Soc., 2007, 129, 42-43.

[19] Y. X. Yang, C. Ochoa-Hernández, P. Pizarro, V. A. de la Peña O'shea, J. M. Coronado, D. P. Serrano., Appl. Catal. B, 2016, 197, 206-213. 


\title{
Graphical Abstract
}

Chin. J. Catal., 2017, 38: 1603-1612 doi: 10.1016/S1872-2067(17)62842-0

Effect of pretreatment conditions on catalytic activity of Ag/SBA-15 catalyst for toluene oxidation

Yuan Qin, Zhenping Qu *, Cui Dong, Na Huang Dalian University of Technology

Redispersed, small Ag particles on the 0500-H300 sample show high activation ability for $\mathrm{O}_{2}$ and great affinity with toluene because of the formation of subsurface oxygen, leading to high catalytic activity for toluene oxidation.

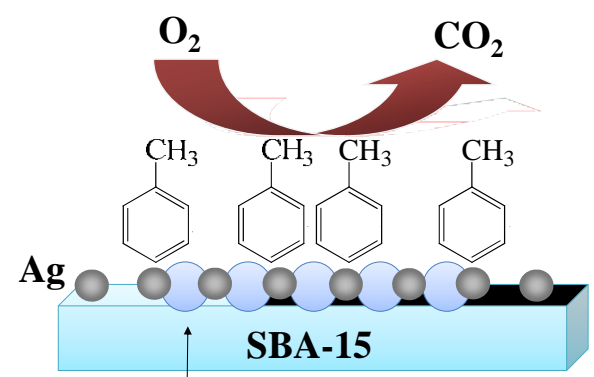

Subsurface oxygen
[20] Y. H. Cheng, L. B. Zhou, J. X. Xu, C. X. Miao, W. M. Hua, Y. H. Yue, Z. Gao, Microporous Mesoporous Mater., 2016, 234, 370-376.

[21] X. D. Zhang, Z. P. Qu, F. L. Yu, Y. Wang, J. Catal., 2013, 297, 264-271.

[22] D. Chen, Z. P. Qu, Y. H. Sun, K. Gao, Y. Wang, Appl. Catal. B, 2013, 142-143, 838-848.

[23] E. Van Steen, G. S. Swell, R. A. Makhothe, C. Miklethwaite, H. Manstein, M. de Lange, C. T. O'Connor, J. Catal., 1996, 162, 220-229.

[24] L. M. Chen, D. Ma, X. H. Bao, J. Phys. Chem. C, 2007, 111, 2229-2242.

[25] W. B. Li, M. Zhang, J. X. Wang, Catal. Today, 2008, 137, 340-344.

[26] H. Li, H. Li, W. L. Dai, J. F. Deng, Appl. Catal. A, 2001, 207, 151-157.

[27] K. J. Kim, H. G. Ahn, Appl. Catal. B, 2009, 91, 308-318.

[28] L. Savio, A. Gerbi, L. Vattuone, R. Pushpa, N. Bonini, S. de Gironcoli, M. Rocca, J. Phys. Chem. C, 2007, 111, 10923-10930.

[29] X. D. Zhang, Z. P. Qu, F. L. Yu, Y. Wang, X. Zhang, J. Mol. Catal. A, 2013, 370, 160-166.

[30] Z. P. Qu, M. J. Cheng, W. X. Huang, X. H. Bao, J. Catal., 2005, 229, 446-458.

[31] Z. P. Qu, W. X. Huang, M. J. Cheng, X. H. Bao, J. Phys. Chem. B, 2005, 109, 15842-15848.

[32] B. Wang, D. Weng, X. D. Wu, J. Fan, Catal. Today, 2010, 153, 111-117.

[33] K. S. W. Sing, D. H. Everett, R. A. W. Haul, L. Moscou, R. A. Pierotti, J. Rouque'rol, T. Siemieniewska, Pure Appl. Chem., 1985, 57, 603-619.

[34] S. C. Kim, J. H. Moon, J. Nanosci. Nanotechnol, 2011, 11, 1660-1663.
[35] A. Aboukaïs, M. Skaf, S. Hany, R. Cousin, S. Aouad, M. Labaki, E. Abi-Aad, Mater. Chem. Phys., 2016, 177, 570-576.

[36] H. G. Yang, J. G. Deng, Y. X. Liu, S. H. Xie, Z. X. Wu, H. X. Dai, J. Mol. Catal. A, 2016, 414, 9-18.

[37] X. Y. Liu, A. Q. Wang, T. Zhang, D. S. Su, C. Y. Mou, Catal. Today, 2010, 160, 103-108.

[38] X. She, M. Flytzani-Stephanopoulos, J. Catal., 2006, 237, 79-93.

[39] A. Keshavaraja, X. She, M. Flytzani-Stephanopoulos, Appl. Catal. B, 2000, 27, L1-L9.

[40] G. Mie, Ann. Phys. 1908, 25, 377-445.

[41] K. Shimizu, J. Shibata, H. Yoshida, A. Satsuma, T. Hattori, Appl. Catal. B, 2001, 30, 151-162.

[42] R. T. Yang, A. J. Herna'ndez-Maldonado, F. H. Yang, Science, 2003, 301, 79-81.

[43] A. J. Herna'ndez-Maldonado, R. T. Yang, AIChE J., 2004, 50, 791-801.

[44] K. Kosuge, S. Kubo, N. Kikukawa, M. Takemori, Langmuir, 2007, 23, 3095-3102.

[45] W. G. Shim, S. C. Kim, H. C. Kang, S. W. Nahm, J. W. Lee, H. Moon, Appl. Surf. Sci., 2007, 253, 5868-5875.

[46] W. G. Shim, J. W. Lee, S. C. Kim, Appl. Catal. B, 2008, 84, 133-141.

[47] W. G. Shim, S. C. Kim, Appl. Surf. Sci., 2010, 256, 5566-5571.

[48] M. Skotak, D. Lomot, Z. Karpinski, Appl. Catal. A, 2002, 229, 103-115.

[49] S. A. Tan, R. B. Grant, R. M. Lambert, J. Catal., 1987, 104, 156-163.

[50] A. Kokalj, A. D. Corso, S. de Gironcoli, S. Baroni, Surf. Sci., 2003, 532-535, 191-197.

[51] V. V. Dutova, G. V. Mamontova, V. I. Zaikovskii, O. V. Vodyankina., Catal. Today, 2016, 278, 150-156.

\section{预处理条件对Ag/SBA-15催化剂上甲苯催化氧化反应性能的影响}

\author{
秦 媛, 曲振平*, 董 翠, 黄 娜 \\ 大连理工大学环境学院, 工业生态与环境工程教育部重点实验室, 辽宁大连 116024
}

\begin{abstract}
摘要: 甲苯是一种典型的挥发性有机污染物. 近年来, 催化氧化法是一种广泛使用并具有开发潜力的有效去除挥发性有机 污染物的方法, 而贵金属催化剂一直是首选. 介孔二氧化硅材料SBA-15具有规则孔道和较高的比表面积因而在催化领域 中具有较大的应用潜力. 本课题组已对一系列的SBA-15负载的纳米银催化剂的制备和低温催化氧化性能进行了研究, 本 文则通过研究不同预处理处理气氛对Ag/SBA-15催化剂结构以及甲苯催化氧化性能的系统研究, 获得纳米银催化剂结构 与甲苯催化氧化性能间的构效关系, 对新催化剂的结构优化以及甲苯催化净化的低温催化剂开发具有重要的科学意义.
\end{abstract}


研究表明, 处理气氛明显影响了银物种和氧物种的状态, 进而影响了催化剂的催化活性, 先氧气 $\left(500{ }^{\circ} \mathrm{C}\right)$ 后氢气 $\left(300{ }^{\circ} \mathrm{C}\right)$ 处理的 $\mathrm{O} 500-\mathrm{H} 300$ 催化剂对甲苯的反应活性明显优于在 $500{ }^{\circ} \mathrm{C}$ 氧气处理样品 $\mathrm{O} 500$ 及氢气处理样品 $\mathrm{H} 500$. 由 X- 射 线衍射和 $\mathrm{O}_{2}$-程序升温脱附(TPD)可知, 氧气 $500{ }^{\circ} \mathrm{C}$ 处理使催化剂上形成大颗粒银粒子和氧化银粒子, 以及大量次表层氧物 种. 氢气处理使催化剂形成较大的银粒子, 由于未经过氧气处理, 该催化剂上并没有次表层氧的生成. 先氧气处理再氢气 处理后催化剂上形成高分散的小粒径银粒子以及次表层氧物种, 这表明低温氢气处理可以降低银粒子的尺寸并使催化剂 上的银粒子得到再分散, 同时不会影响次表层氧物种的形成. 从催化剂的甲苯吸附和TPD实验中看出, 大尺寸银粒子对甲 苯具有较强的吸附性能, 从而有利于甲苯在低温的催化氧化, 但是在高温反应中没有优势; 小尺寸银粒子虽然对甲苯的吸 附能力不强, 但是对分子氧有较好的吸附作用, 进而增强自身与甲苯的相互作用, 而且也促进了分子氧的活化, 预处理中形 成的次表层氧有效增强了甲苯和银粒子的相互作用, 因此, 先氧气后氢气处理的O500-H300样品在反应中显示出最好的甲 苯催化活性.

关键词: SBA-15; 负载型银催化剂; 预处理条件; 竞争吸附; 甲苯氧化

收稿日期: 2016-12-13. 接受日期: 2017-04-19. 出版日期: 2017-09-05.

*通讯联系人. 传真: (0411)84708083; 电子信箱: quzhenping@dlut.edu.cn 基金来源：国家自然科学基金(21377016, 21577014); 长江学者与创新团队发展计划(IRT_13R05).

本文的英文电子版由Elsevier出版社在ScienceDirect上出版(http://www.sciencedirect.com/science/journal/18722067). 